\title{
Dissolution kinetics of Amazonian metakaolin in nitric acid
}

\section{(Cinética de dissolução de um metacaulim amazônico em ácido nútrico)}

\author{
P. E. A. Lima ${ }^{1 *}$, R. S. Angélica ${ }^{1}$, R. F. Neves ${ }^{2}$ \\ ${ }^{1}$ Programa de Pós-Graduação em Geologia e Geoquímica, Instituto de Geociências; ${ }^{2}$ Programa de Pós- \\ Graduação em Engenharia Química, Faculdade de Engenharia Química, Universidade Federal do Pará, \\ R. Augusto Corrêa s/n, Belém, PA 66075-110 \\ *paulaelissa@gmail.com
}

\begin{abstract}
The kinetic study of Amazon metakaolin dissolution was performed with the application of the shrinking core model for spherical and 'flat plate' particles with constant size. The Amazon kaolin was calcinated at $700{ }^{\circ} \mathrm{C}$ in order to produce metakaolin. This metakaolin was leached with $5 \%$ excess nitric acid at 70,80 and $95 \pm 3{ }^{\circ} \mathrm{C}$ for $3 \mathrm{~h}$. Samples were collected every 15 min and subjected to aluminum analysis. The acid leaching was a chemically controlled process. The spherical morphology showed better fit than the flat plate particles when taking into account the regression coefficients. $91.58 \mathrm{~kJ} / \mathrm{mol}$ of activation energy was found as well as an aluminum leaching reaction of the first order. The results found in this work using 5\% excess acid and Amazon kaolin were consistent with previous research results using excess acid above $50 \%$ and standard kaolin.
\end{abstract}

Keywords: kaolin, metakaolin, leaching, kinetic study.

\section{Resumo}

O estudo cinético da dissolução de um metacaulim amazônico foi realizado com a aplicação do modelo 'shrinking core model' para partículas esféricas e 'placas planas' com tamanho constante. O caulim amazônico foi calcinado a $700{ }^{\circ} \mathrm{C}$ para promover a formação do metacaulim. O metacaulim foi lixiviado utilizando ácido nítrico com excesso de $5 \%$ a 70 , 80 e $95 \pm 3 \quad{ }^{\circ} \mathrm{C}$ por 3 h. Amostras foram coletadas a cada 15 min e submetidas à análise de alumínio. A lixiviação ácida realizada foi um processo quimicamente controlado. A morfologia esférica mostrou melhor ajuste matemático do que a morfologia de placa plana levando-se em consideração os coeficientes de regressão obtidos. Foi encontrada uma energia de ativação equivalente a 91,58 $\mathrm{kJ} / \mathrm{mol}$, assim como reação de lixiviação de primeira ordem em relação ao alumínio do metacaulim. Os resultados encontrados com a utilização de excesso ácido de apenas $5 \%$ e caulim amazônico foram consistentes com trabalhos realizados anteriormente, cuja metodologia utilizou excesso ácido acima de $50 \%$ e amostra padrão de caulim.

Palavras-chave: caulim, metacaulim, lixiviação, estudo cinético.

\section{INTRODUCTION}

There are kaolin mines located in the Amazon region of northern Brazil, specifically in the states of Amapá (Rio Jari) and Pará (Rio Capim). Kaolin is mainly used in the paper industry as a filler and cover. However, it is also a possible source of metallic aluminum, porous silica, aluminum sulfate, chloride and nitrate [1-9]. Currently, bauxite is used for metallic aluminum production, but the limited availability of bauxite in the world makes researchers look for other available resources. Kaolin is a possible alternative to bauxite because it contains high alumina concentrations and is abundant in the Amazon region. The aluminum production process using kaolin can also produce silica with high specific area [10-13].

The aluminum extraction from kaolin is carried out by first performing the calcination and then the leaching process. The calcination of the kaolin promotes metakaolin production $\left(\mathrm{Al}_{2} \mathrm{Si}_{2} \mathrm{O}_{7}\right)$ through the dehydroxylation process [14-17]. The metakaolin produced from calcination can then be subjected to an acid leaching process which promotes aluminum dissolution [18]. The main acids used in this process are: hydrochloric, sulfuric and nitric acid [10, 13]. The following reaction represents the nitric acid leaching of metakaolin:

$\mathrm{Al}_{2} \mathrm{Si}_{2} \mathrm{O}_{7(\mathrm{~S})}+6 \mathrm{HNO}_{3(1)} \rightarrow 2 \mathrm{Al}\left(\mathrm{NO}_{3}\right)_{3(1)}+2 \mathrm{SiO}_{2(\mathrm{~S})}+3 \mathrm{H}_{2} \mathrm{O}_{(1)}$

The kinetic study of this process has already been examined by many researchers. Hulbert and Huff [10] carried out a kinetic study of calcinated kaolin dissolution with three different acids: sulfuric, hydrochloric and nitric. Ajemba and Onukwuli [12] studied the dissolution kinetics and reaction mechanisms of Udi clay with an excess of nitric acid above $50 \%$ of the required stoichiometry. Phillips and Wills [19], Olsen et al. [20], and others studied the aluminum dissolution process of kaolinitic clays. However, previous work found in the literature dealing with kinetic studies of metakaolin aluminum dissolution with nitric acid did not use Amazon metakaolin and used acid excess above 50\%. 
The high excess of acid which is recommended by literature for this kinetic study is not industrially viable. Therefore, the aim of this paper is to carry out a kinetic study of the metakaolin aluminum dissolution process using Amazon kaolin as starting material and then leaching it with nitric acid at 5\% excess. The shrinking core model (SCM) is then applied for spherical and 'flat plate' particles with constant size.

\section{MATERIALS AND METHODS}

Materials: the starting materials were kaolin (a final product used for paper coating) from the Capim region in the state of Pará and nitric acid ( $65 \%$ purity). The nitric acid was used in concentrations to produce aluminum/acid rates similar to the reaction stoichiometry with $5 \%$ excess. The leachings were carried out in a reactor with a heating mantle capacity of $1000 \mathrm{~mL}$, under constant stirring and refluxing, and coupled with a thermometer and a thermostat.

Methods: the kaolin was dried at $110^{\circ} \mathrm{C}$ and calcinated in a muffle furnace at $700{ }^{\circ} \mathrm{C}$ for $2 \mathrm{~h}$. The calcinated kaolin was named MK700. The non-calcinated kaolin and MK700 were leached with nitric acid at $5 \%$ excess. Leaching tests were carried out for $3 \mathrm{~h}$ with $50 \mathrm{~g}$ of sample. The non-calcinated kaolin was leached at $95 \pm 3{ }^{\circ} \mathrm{C}$ and MK700 at 95,80 and $70 \pm 3{ }^{\circ} \mathrm{C}$. Samples were collected every $15 \mathrm{~min}$, filtered and subjected to aluminum analysis using EDTA titrimetric method. Leachings were carried out in duplicate and the solid residue was named MKA700. The mathematical adjustments were carried out in Microsoft Excel using the Solver tool with the hyperbole equation.

The materials were characterized before and after the calcination and leaching processes according to the following techniques: 1) X-ray diffraction analysis (XRD), using an X'PERT PRO MPD (PW 3040/60) from Panalytical, CuKa $\left(\mathrm{K} \alpha_{1}=1.54060 \AA\right)$ radiation, Ni $\beta$ filter, $4^{\circ}-75^{\circ}(2 \theta)$, step size of $0.017^{\circ}(2 \theta)$, time/step of $20 \mathrm{~s}$, voltage of $40 \mathrm{kV}$ and slit width of $1 / 4^{\circ} ; 2$ ) chemical analysis by X-ray fluorescence spectrometry (XRF) using an Axios Minerals WDS, Panalytical spectrometer; 3) particle size distribution (PSD) using an Analysette 22 MicroTec Plus, from Fritsch; and 4) scanning electron microscopy (SEM) analysis in an LEO 1430 Zeiss equipment.

Table I - Final equations of the shrinking core model for spherical and flat plate particles with constant size.

[Tabela I - Equações finais do modelo 'shrinking core model' para particulas esféricas e placa plana.]

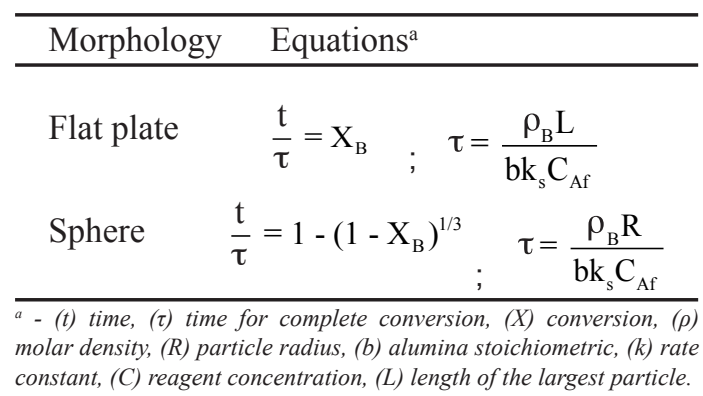

The shrinking core model (SCM) was used in the kinetic study for spherical and flat plate particles with constant size (heterogeneous reaction). The activation energy was calculated using the Arrhenius equation [13, 21-23]. Table I shows the equations used.

\section{RESULTS AND DISCUSSION}

Material characterization: Fig. 1 shows the XRD patterns of kaolin for MK700 and MKA700. Kaolinite was predominant in kaolin, but small amounts of anatase were observed. MK700 and MKA700 were both shown to be in amorphous phase. Table II shows the chemical composition of these materials. The micromorphological analysis showed that the kaolin was composed of pseudo-hexagonal plates, which is typical of kaolinite. This micromorphological aspect remained even after the calcination and leaching processes which can be seen in Fig. 2 [24]. Concerning the PSD analysis (Fig. 3), the kaolin showed an average particle size $\left(D_{50}\right)$ of $3 \mu \mathrm{m}$. Calcination and leaching did not promote significant changes in the particle size, with $\mathrm{D}_{50}$ of $4.1 \mu \mathrm{m}$ and $4.9 \mu \mathrm{m}$ for MK700 and MKA700, respectively.

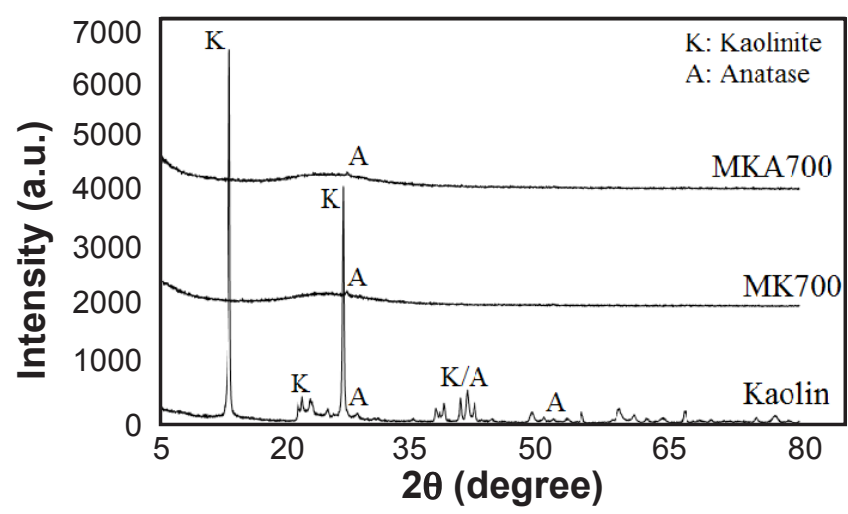

Figure 1: X-ray diffraction patterns of kaolin, MK700 and MKA700.

[Figura 1: Difratogramas de raios $X$ do caulim, MK700 e MKA700.]

Acid leaching: the fractional conversions obtained from the leachings are shown in Fig. 4. The final conversion values obtained were as follow: $95.9 \%$ at $95{ }^{\circ} \mathrm{C}, 79.9 \%$ at $80{ }^{\circ} \mathrm{C}$ and $44.6 \%$ at $70{ }^{\circ} \mathrm{C}$ for MK 700 and $4.5 \%$ at $95^{\circ} \mathrm{C}$ for non-calcinated kaolin.

Kinetic study: the shrinking core model (SCM) was applied for spherical and flat plate particles with constant size with the chemical reaction as a determining step. The results found were similar (Fig. 5, Table III). Differences between the rate constant can be attributed to the changes in the reaction area considered. The reaction was of the first-order with respect to aluminum from metakaolin and had an activation energy of 91.58 and $91.78 \mathrm{~kJ} / \mathrm{mol}$ for spherical and flat plate particles, respectively. The spherical morphology showed a better fit with regression coefficients very close to 1 . Therefore, the results obtained for spherical particles were considered for the final analysis of this study.

Some authors carried out metakaolin leachings with nitric 
Table II - Chemical composition of samples - major oxides (mass \%).

[Tabela II - Composição química das amostras - principais óxidos (\% em massa).]

\begin{tabular}{ccccccc}
\hline Sample & $\mathrm{SiO}_{2}$ & $\mathrm{Al}_{2} \mathrm{O}_{3}$ & $\mathrm{Fe}_{2} \mathrm{O}_{3}$ & $\mathrm{Na}_{2} \mathrm{O}$ & $\mathrm{TiO}_{2}$ & LOI $^{\mathrm{a}}$ \\
\hline Kaolin & 45.96 & 38.50 & 0.53 & 0.22 & 0.42 & 14.29 \\
MK700 & 52.99 & 44.63 & 0.56 & 0.34 & 0.50 & 0.98 \\
MKA700 & 78.52 & 1.92 & 0.41 & 0.02 & 0.81 & 18.30 \\
\hline
\end{tabular}

a - loss on ignition.
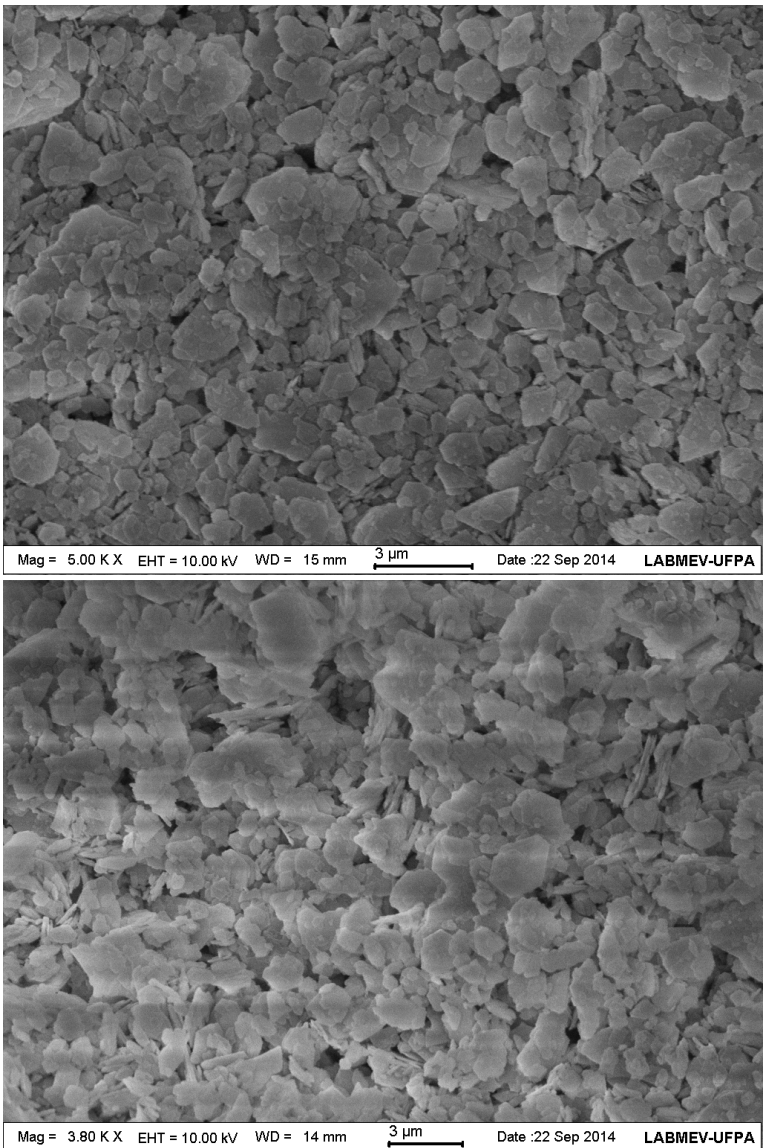

b)

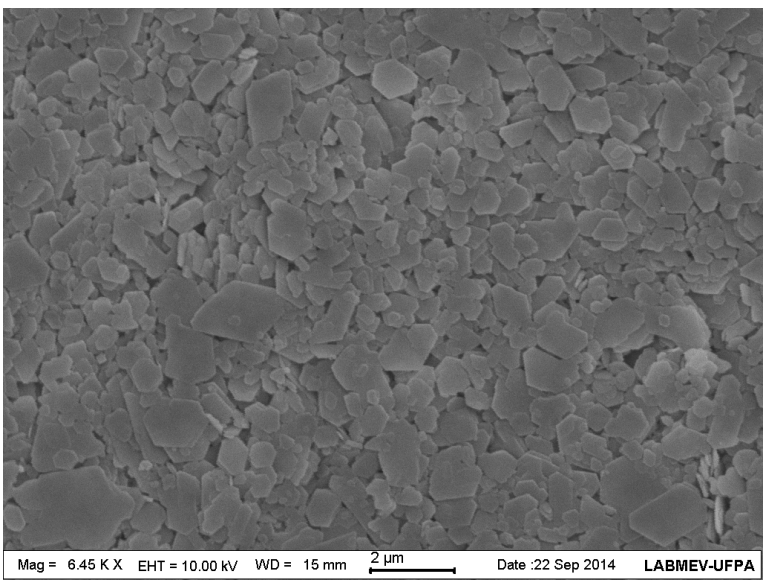

c)

Figure 2: SEM micrographs of kaolin (A), MK700 (B), and MKA700 (C).

[Figura 2: Micrografias obtidas por microscopia eletrônica de varredura do caulim (A), MK700 (B) e MKA700 (C).]

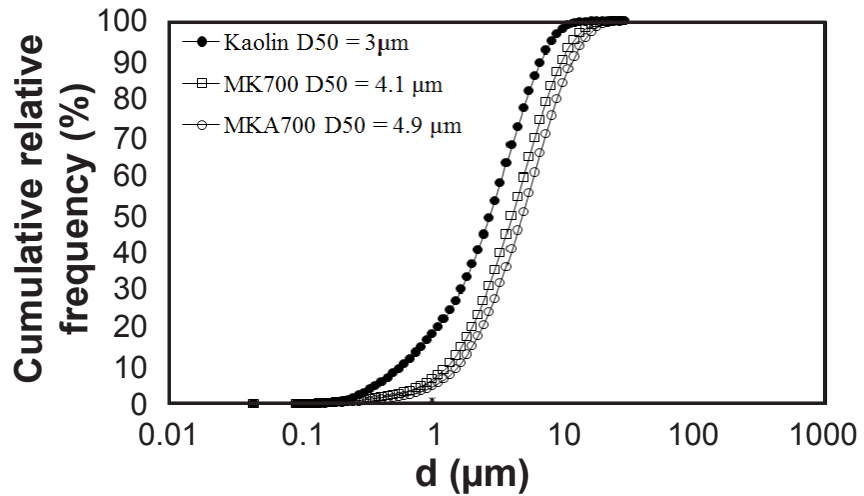

Figure 3: PSD curves of kaolin (non-calcinated), MK700 and MKA700 (d: particle size, D50: average particle size).

[Figura 3: Curvas de distribuição de tamanho de partícula do caulim (não calcinado), MK700 e MKA700 (d: diâmetro de partícula, D50: diâmetro médio de partícula).]

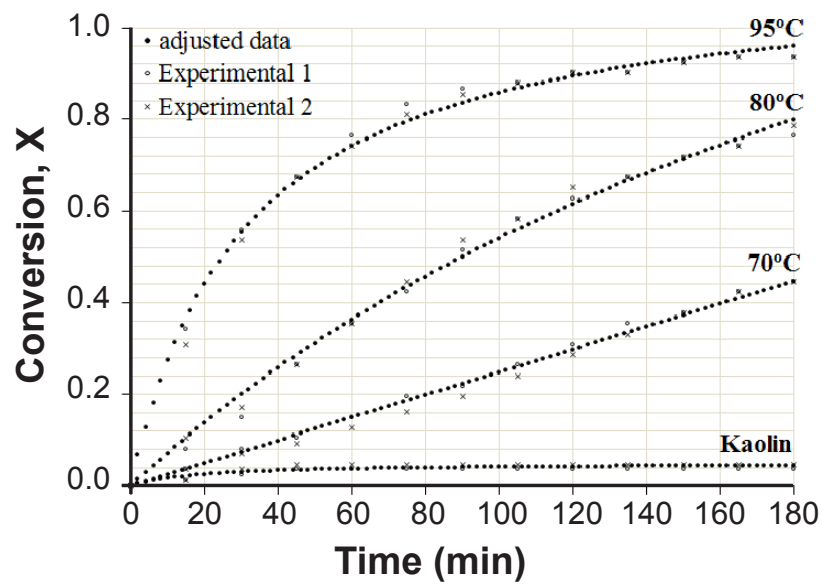

Figure 4: Fractional conversions (X) of leachings with $\mathrm{HNO}_{3}$ at 95 , 80 and $70{ }^{\circ} \mathrm{C}$ for MK700 and at $95^{\circ} \mathrm{C}$ for kaolin (non-calcinated). [Figura 4: Conversão fracional $(X)$ das lixiviações com $\mathrm{HNO}_{3}$ a 95, 80 e $70{ }^{\circ} \mathrm{C}$ para o MK700 e a $95{ }^{\circ} \mathrm{C}$ para o caulim (não calcinado).]

acid. Hulbert and Huff [10] studied the kinetics of alumina removal from a calcinated kaolin with nitric, sulphuric and hydrochloric acids (excess above 90\%). A nucleation model was applied and concluded that the reaction with respect to aluminum was of the first order and had an activation energy of $108.68 \mathrm{~kJ} / \mathrm{mol}$. Ajemba and Onukwuli [12] investigated the dissolution kinetics and mechanisms of reaction of Udi clay in a nitric acid solution (excess above $90 \%$ ). The clay was calcinated at $700{ }^{\circ} \mathrm{C}$ and showed extractable alumina concentrations of $26.5 \%$ with a high concentration of $\mathrm{Fe}_{2} \mathrm{O}_{3}$ $(18.45 \%)$ and the presence of interferents such as $\mathrm{K}_{2} \mathrm{O}$, $\mathrm{SO}_{3}, \mathrm{MgO}$ and others. The leachings were carried out at temperatures between $30-70{ }^{\circ} \mathrm{C}$ with maximum extraction being less than $70 \%$ at $70{ }^{\circ} \mathrm{C}$. They concluded that it was a chemically controlled process with reaction order and activation energy of 0.31 and $21.79 \mathrm{~kJ} / \mathrm{mol}$, respectively. The activation energy found in this study $(91.58 \mathrm{~kJ} / \mathrm{mol})$, carried out in nitric acid with $5 \%$ excess, was consistent with the first paper, but had a significant difference with the second 

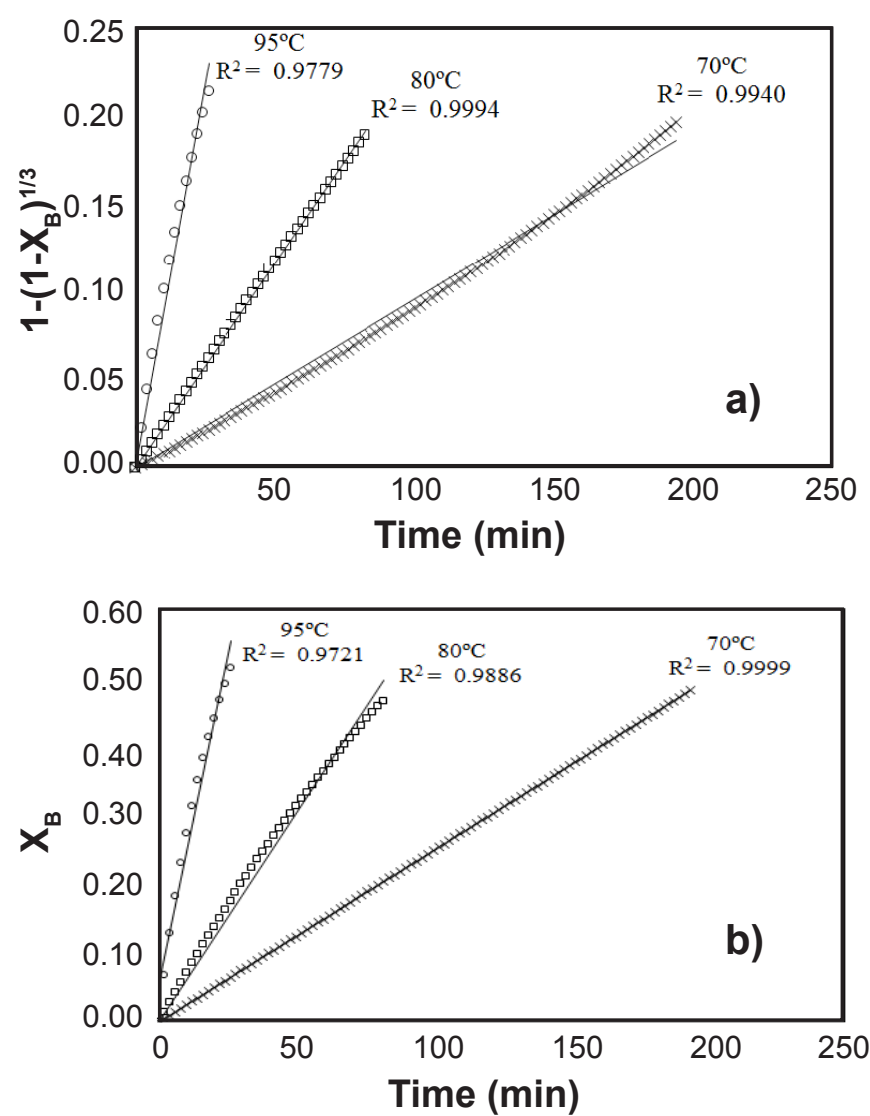

Figure 5: Regression coefficients $\left(\mathrm{R}^{2}\right)$ for: (a) spherical particle; and (b) flat plate particle ( $\mathrm{X}_{\mathrm{B}}$ : fractional conversion).

[Figura 5: Coeficientes de regressão $\left(R^{2}\right)$ para: (a) partícula esférica; e (b) partícula placa plana $\left(X_{B}\right.$ : conversão fracional).]

paper. This difference was attributed to the starting material. The Amazon kaolin used in this work showed chemical composition not compatible with Udi clay, studied by Ajemba and Onukwuli, with low concentration of $\mathrm{Al}_{2} \mathrm{O}_{3}$ and high concentration of $\mathrm{Fe}_{2} \mathrm{O}_{3}$. The starting material used in this study had chemical composition similar to the standard samples of kaolin (Huber CW) used in [10] $\left(42.9 \% \mathrm{Al}_{2} \mathrm{O}_{3}\right.$, $0,4 \% \mathrm{Fe}_{2} \mathrm{O}_{3}$ and $1.8 \% \mathrm{TiO}_{2}$ ). In the kinetic study, the high purity gives a greater transparency because there are less errors involved. The kaolin from the Amazon region used in this study showed low concentrations of contaminants due to its sedimentary origin [8], with chemical composition close to standards samples of kaolin.

\section{CONCLUSIONS}

The results of the kinetic parameters obtained for spherical and 'flat plate' morphologies were similar. However, the regression coefficient values indicated that the spherical morphology showed a better fit. The aluminum dissolution of metakaolin in nitric acid is a chemically controlled process, is a first-order reaction with respect to aluminum and has an activation energy of $91.58 \mathrm{~kJ} / \mathrm{mol}$. The Amazon metakaolin studied in this work leached with nitric acid at $95{ }^{\circ} \mathrm{C}$ and $5 \%$ excess showed maximum aluminum extraction $(95.9 \%)$. These kinetic results are consistent with studies carried out previously with compatible starting materials and acid excess above $90 \%$.

\section{ACKNOWLEDGMENTS}

The first author thanks $\mathrm{CNPq}$ for a $\mathrm{PhD}$ scholarship. Financial resources for this work were obtained from the following projects related to zeolite synthesis from Amazon kaolin: MCT/CT-Mineral/Vale/CNPq n ${ }^{\circ}$ 12/2009 (Process 550.297/2010-3) and $\mathrm{n}^{\circ}$ 01/2010, FAPEMIG-FAPESPFAPESPA-VALE (ICAAF n ${ }^{\circ}$ 027/2011).

\section{REFERENCES}

[1] H.H. Morris, F.A. Gunn, Ind. Eng. Chem. 52, 5 (1960) 370.

[2] B.S. Carneiro, R.S. Angélica, T. Scheller, E.A.S. Castro, R.F. Neves, Cerâmica 49 (2003) 237.

[3] H.H. Murray, C.A. Alves, C.H. Bastos, Clay Miner. 42 (2007) 145.

[4] A.A.B. Maia, E. Saldanha, R.S. Angélica, C.A.G. Souza, R.F. Neves, Cerâmica 53 (2007) 319.

[5] W.N. Mussel, E. Murad, P.S.R. Criscuolo, P.G. Pinheiro, J.D. Fabris, Clay Miner. 43, 3 (2008) 381.

[6] A.A.B. Maia, R.S. Angélica, R.F. Neves, Cerâmica 54 (2008) 345.

[7] M.L. Costa, D.J.L. Sousa, R.S. Angelica, J. South Am. Earth Sci. 27, 2-3 (2009) 219.

[8] E. Santos, R.B. Scorzelli, L.C. Bertolino, O.C. Alves, P. Munayco, Appl. Clay Sci. 55 (2012) 164.

[9] M.S. Barata, R.S. Angélica, Cerâmica 58 (2012) 36.

[10] S.F. Hulbert, D.E. Huff, J. Clay Miner. 8 (1970) 337.

[11] A.A. Al-Zahrani, M.H. Abdul-Majid, JKAU: Eng. Sci.

Table III - Results obtained with SCM for spherical and flat plate particles. ${ }^{a}$ [Tabela III - Resultados obtidos com o SCM para partículas esférica e placa plana. ${ }^{a}$ ]

\begin{tabular}{ccccccc}
\hline $\mathrm{T}$ & \multicolumn{3}{c}{ Sphere } & \multicolumn{3}{c}{ Flat plate } \\
$\left({ }^{\circ} \mathrm{C}\right)$ & $\mathrm{n}$ & $\mathrm{k}\left(\mathrm{min}^{-1}\right)$ & $\mathrm{Ea}(\mathrm{kJ} / \mathrm{mol})$ & $\mathrm{n}$ & $\mathrm{k}\left(\mathrm{min}^{-1}\right)$ & $\mathrm{Ea}(\mathrm{kJ} / \mathrm{mol})$ \\
\hline 70 & 0.99 & 0.0010 & & 1.00 & 0.0025 & \\
80 & 1.00 & 0.0023 & 91.58 & 0.98 & 0.0060 & 91.78 \\
95 & 0.91 & 0.0088 & & 0.86 & 0.0222 & \\
\multicolumn{1}{c}{ - $n:$ reaction order; k: rate constant; Ea: activation energy. }
\end{tabular}


20, 2 (2009) 29.

[12] R.O. Ajemba, O.D. Onukwuli, Am. J. Sci. Ind. Res. 3, 3 (2012) 115.

[13] P.E.A. Lima, R.S. Angélica, R.F. Neves, Appl. Clay Sci. 88-89 (2014) 159.

[14] G.W. Brindley, M. Nakahira, J. Am. Ceram. Soc. 42, 7 (1959) 314.

[15] S. Sperinck, P. Raiteri, N. Marks, K. Wright, J. Mater. Chem. 21 (2010) 2118.

[16] P.E.A. Lima, R.S. Angélica, T. Scheller, R.F. Neves, Cerâmica 59 (2013) 317.

[17] P.S. Santos, Ciência e tecnologia de argilas, $2^{\text {nd }}$ Ed., Edgar Blücher, S. Paulo (1989).

[18] C. Belver, M.A.B. Muñoz, M.A. Vicente, Chem. Mater.
14, 5 (2002) 2033.

[19] C.V. Phillips, K.J. Wills, Hydrometallurgy 9 (1982) 15. [20] R.S. Olsen, W.G. Gruzensky, S.J. Bullard, R.P. Beyer, J.L. Henry, Report of Investigations RI8834, Bureau of Mines, USA (1983).

[21] O. Levenspiel, Chemical reaction engineering, John Wiley, New York (1972).

[22] H.S. Fogler, Elements of chemical reaction engineering, Prentice Hall, New Jersey (1999).

[23] J.C. Kotz, P. Treichel, Chemistry and chemical reactivity, Saunders College Publ., Florida (1999).

[24] F. Bergaya, P. Dion, J.F. Alcover, C. Clinard, D. Tchoubar, J. Mater. Sci. 31 (1996) 5069.

(Rec. 20/10/2016, Rev. 18/03/2017, 22/05/2017, Ac. 20/06/2017) 